\title{
Glypican-1 regulates myoblast response to HGF via Met in a lipid raft-dependent mechanism: effect on migration of skeletal muscle precursor cells
}

\author{
Jaime Gutiérrez, Daniel Cabrera and Enrique Brandan*
}

\begin{abstract}
Background: Via the hepatocyte growth factor receptor (Met), hepatocyte growth factor (HGF) exerts key roles involving skeletal muscle development and regeneration. Heparan sulfate proteoglycans (HSPGs) are critical modulators of HGF activity, but the role of specific HSPGs in HGF regulation is poorly understood. Glypican-1 is the only HSPG expressed in myoblasts that localize in lipid raft membrane domains, controlling cell responses to extracellular stimuli. We determined if glypican-1 in these domains is necessary to stabilize the HGF-Met signaling complex and myoblast response to HGF.
\end{abstract}

Methods: C2C12 myoblasts and a derived clone (C6) with low glypican-1 expression were used as an experimental model. The activation of Met, ERK1/2 and AKT in response to HGF was evaluated. The distribution of Met and its activated form in lipid raft domains, as well as its dependence on glypican-1, were characterized by sucrose density gradient fractionation in both cell types. Rescue experiments reexpressing glypican-1 or a chimeric glypican-1 fused to the transmembrane and cytoplasmic domains of mouse syndecan-1 or myoblast pretreatment with $M \beta C D$ were conducted. In vitro and in vivo myoblast migration assays in response to HGF were also performed.

Results: Glypican-1 localization in membrane raft domains was required for a maximum cell response to HGF. It stabilized Met and HGF in lipid raft domains, forming a signaling complex where the active phospho-Met receptor was concentrated. Glypican-1 also stabilized CD44 in a HGF-dependent manner. In addition, glypican-1 was required for in vitro and in vivo HGF-dependent myoblast migration.

Conclusions: Glypican-1 is a regulator of HGF-dependent signaling via Met in lipid raft domains.

Keywords: Glypican-1, Heparan sulfate proteoglycans, Hepatocyte growth factor, HGF-mediated signaling, Raft membrane domains, Skeletal muscle

\section{Background}

The process of skeletal muscle regeneration is initiated immediately after injury by the release of growth factors and cytokines from injured muscles, blood vessels, infiltrating inflammatory cells and extracellular matrix (ECM) reservoirs. These factors include basic fibroblast growth factor 2 (FGF-2) and hepatocyte growth factor (HGF) [1-3]. The factors promote the activation, proliferation, migration and survival of satellite cells (SCs), which are the muscle stem cells responsible for the formation of new

\footnotetext{
* Correspondence: ebrandan@bio.puc.cl

Centro de Regulación Celular y Patología (CRCP), Centro de Regeneración y Envejecimiento (CARE), Departamento de Biología Celular y Molecular, MIFAB, Pontificia Universidad Católica de Chile, Santiago, Chile
}

muscle fibers [2]. HGF was originally identified as a scatter factor because of its ability to increase the motility of several normal and neoplastic cells $[4,5]$. The requirement of HGF for migration of muscle precursor cells during mouse muscle development has been established by the genetic ablation of HGF or the HGF receptor (Met). In both cases, the result was the absence of hindlimb muscles, which are formed by muscle precursor cells that migrate from the dermomyotome [6-8]. In vitro studies have shown that HGF not only induces the proliferation and migration of myogenic cells but that it also delays muscle differentiation by inhibiting the expression of MyoD and myogenin, two master myogenic regulatory transcription factors $[3,9,10]$. The expression of HGF and Met are downregulated during 
myogenesis, which is consistent with attenuation of myogenic inhibitory signaling of HGF [11-13]. Therefore, HGF plays key role during myogenesis, regulating the proliferation, migration and subsequent differentiation of muscle precursor cells.

Upon HGF binding, Met is activated by dimerization with subsequent trans-phosphorylation of four tyrosine residues which act as docking motifs for signaling mediators, including mitogen-activated protein kinase (MAPK), extracellular signal-regulated kinases 1 and 2 (ERK1/2) and phosphoinositide 3-kinase protein kinase B (AKT), among others [14-16].

It has been proposed that HGF and Met form a complex in lipid rafts, which are sphingolipid- and cholesterol-rich domains that form phase-separated lipid rafts in the membrane. In these domains, Met is stabilized by HGF to induce its activation [17-20].

Another important component of the HFG-Met signaling is the ubiquitous transmembrane glycoprotein CD44, the major receptor for hyaluronic acid [21,22]. In different cell types, the activation of the MET receptor by HGF depends on the presence of some isoforms of CD44 [21]. As proposed, HGF, Met and CD44 would form a complex in lipid raft membrane domains, which corresponds to sphingolipid- and cholesterol-rich domains forming phase-separated lipid rafts in the membrane, where Met would be stabilized by HGF inducing its activation $[17,18]$.

HGF also binds to heparin, heparan sulfate (HS) and dermatan sulfate [23-27]. Heparan sulfate proteoglycans (HSPGs), key components of the cell surface and the ECM, regulate many processes related to cell growth and differentiation. Cell-surface HSPGs bind soluble ligands, increasing their local concentration and modulating ligand-receptor interactions [28]. For example, HSPG is required for FGF-2-dependent signaling through its receptors (FGFRs) [29-32], forming the ternary complex HSPGFGF-2-FGFR [33]. However, the exact role of HSPG in HGF signaling is poorly understood. In vitro assays have shown that heparin increases the mitogenic effect of HGF and facilitates its oligomerization, inducing Met dimerization and activation [34]. Previously, we showed that myoblast migration induced by HGF was strongly inhibited if the cells were depleted of HS chains, indicating that at least the myoblast cell response to HGF depended on HS [23].

We have also previously shown that myoblasts express different membrane-bound HSPGs, the four transmembrane syndecans and glypican-1, which corresponds to a glycosylphosphatidylinositol-anchored HSPG [31,32,35-39]. Glypican-1 is the only HSPG located in lipid raft microdomains, which sequester FGF-2 to avoid its interaction with FGFRs. Thus, glypican-1-deficient cells exhibit enhanced sensitivity to FGF-2. In contrast, HGF-dependent signaling was clearly decreased in the absence of glypican-1, suggesting that glypican-1 was a positive regulator of HGF signaling [38].

Because HGF and Met are found in lipid raft domains [17-20], we hypothesize that glypican-1 in these domains is necessary to stabilize the HGF-Met signaling complex. In the present study, we report that the presence of glypican-1 in lipid rafts was required for maximum HGFdependent signaling, localizing and stabilizing HGF and Met in its phosphorylated or activated state (phosphoMet). We also show that glypican-1, phospho-Met and HGF interact, indicating that they form part of a signaling complex in lipid rafts. Finally, we show that glypican-1 is required for myoblast migration induced by HGF in vitro and in vivo, demonstrating the requirement of glypican-1 expression and HGF for processes such as muscle stem cell therapy, where the migration of myoblasts must be enhanced.

\section{Methods}

\section{Cell culture}

The mouse skeletal muscle cell line $\mathrm{C} 2 \mathrm{C} 12$ (American Type Culture Collection, Manassas, VA, USA) [40] and its derived clone deficient in glypican-1 expression [38] were grown as previously described [31,38]. Myoblasts were treated with HGF (R\&D Systems, Minneapolis, MN, USA) as indicated in each experiment. Methyl- $\beta$-cyclodextrin (MßCD) (Sigma-Aldrich, St Louis, MO, USA) treatment at 1 or $10 \mathrm{mM}$ concentrations were performed as previously described [38]. For the phosphorylation experiments of Met, ERK1/2 and AKT, the cells were serum-starved for 6 hours and then treated for the indicated times.

\section{Transient transfection and generation of stable clones}

The pcDNA3.0 empty vector (Invitrogen, Carlsbad, CA, USA) and pcDNA3.0 vectors containing rat glypican-1 and chimeric HSPG comprising the extracellular domain of rat glypican-1 were fused to the transmembrane and cytoplasmic domains of mouse syndecan-1 containing a FLAG epitope in their amino-terminal F-Gly and FGlySyn, respectively [38]. Transfection were carried out using Lipofectamine and PLUS reagents (Invitrogen) according to the supplier's protocol.

\section{Isolation of lipid rafts}

Lipid rafts were prepared as described previously, with some modifications [38]. All of the buffers and instruments used in the procedure described below were used at $4^{\circ} \mathrm{C}$. Briefly, C2C12 myoblasts from a $150-\mathrm{mm}$ dish were

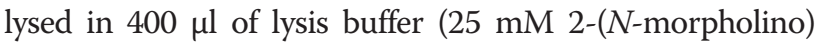
ethanesulfonic acid, $\mathrm{pH} 6.5,150 \mathrm{mM} \mathrm{NaCl}$, with a mixture of protease inhibitors and $1 \mathrm{mM}$ phenylmethanesulfonyl fluoride supplemented with $1 \%$ Triton X-100). Cells were incubated for 20 minutes on ice, then homogenized with 
ten strokes of a loose-fitting Dounce homogenizer. Homogenates were mixed with $400 \mu \mathrm{l}$ of $90 \%$ sucrose $(45 \%$ final concentration), loaded at the bottom of a Sorvall 4-ml centrifuge tube (Thermo Scientific, Asheville, NC, USA) and overlaid with $1.6 \mathrm{ml}$ of $35 \%$ sucrose and $1.6 \mathrm{ml}$ of $5 \%$ sucrose, both in the lysis buffer without Triton X-100. The samples were centrifuged at $45,000 \mathrm{rpm}$ for 18 hours at $4^{\circ} \mathrm{C}$ in an AH-650 rotor. Twelve fractions (330 $\mu \mathrm{l}$ each) were collected from top to bottom and designated as fractions 1 to 12 . Only the last ten fraction were analyzed, because the low-density lipid raft-enriched fractions started at fraction 5 in several previous assays that we performed.

SDS-PAGE, Western blot and coimmunoprecipitation assays Aliquots from the last ten fractions of the different sucrose density fractionations were separated on $8 \%$ SDS-PAGE gels (Mini-PROTEAN II; Bio-Rad Laboratories, Hercules, CA, USA) and electrophoretically transferred to Immobilon membranes (EMD Millipore, Bedford, MA, USA). Western blots were probed using the following primary antibodies: rabbit anti-mouse Met (1:200) (Santa Cruz Biotechnology, Santa Cruz, CA, USA), rabbit anti-phospho-Met at Tyr 1234 and Tyr 1235 (1:1,000) (Cell Signaling Technology, Danvers, MA, USA), rabbit anti-caveolin-1 (1:500) (Santa Cruz Biotechnology), rabbit anti-glypican-1 M-95 (1:500) (Santa Cruz Biotechnology), mouse anti- $\mathrm{Na}^{+} / \mathrm{K}^{+}$-ATPase $(1: 1,000)$ (Upstate Biotechnology, Lake Placid, NY, USA) and rat anti-CD44 (1:500) (BD Pharmingen, San Jose, CA, USA).

To identify glypican-1, samples containing equivalent amounts of protein were treated with heparitinase and chondroitinase ABC (United States Biological, Swampscott, MA, USA) as previously described [39,41] prior to SDSPAGE and Western blot analysis using anti-glypican-1 M95 antibody.

For analysis of phosphorylated proteins, cell extracts were prepared in radioimmunoprecipitation assay (RIPA) buffer in the presence of phosphatase inhibitors as previously described $[38,42]$. Aliquots with equivalent amounts of protein were subjected to SDS-PAGE in $8 \%$ polyacrylamide gels, electrophoretically transferred to Immobilon membranes (EMD Millipore) and probed with the following antibodies: rabbit anti-phospho-ERK1/2 (1:1,000), mouse anti-FLAG $(1: 5,000)$ (Stratagene, La Jolla, CA, USA), rabbit anti-ERK1/2 (1:1,000), rabbit anti-phospho-AKT $(1: 1,000)$ (Calbiochem, San Diego, CA, USA), mouse anti$\alpha$-tubulin (1:5,000) (Sigma-Aldrich), mouse anti-myosin $(1: 5,000)$ (Sigma-Aldrich) and mouse anti-glyceraldehyde 3-phosphate dehydrogenase $(1: 2,000)$ (Chemicon International, Temecula, CA, USA). All immunoreactions were visualized by enhanced chemiluminescence (Pierce Biotechnology, Rockford, IL, USA) using a ChemiDoc-It 410 high-resolution imaging system (UVP, Upland, CA, USA).
For coimmunoprecipitation experiments, wild-type and glypican-1-deficient myoblasts (C6) were transiently transfected as indicated in the figure legends. At 48 hours after transfection, cells were serum-starved for 4 hours, then either treated or not treated with $20 \mathrm{ng} / \mathrm{ml}\left[{ }^{125} \mathrm{I}\right] \mathrm{HGF}$ in Dulbecco's modified Eagle's medium (DMEM) 0.1\% bovine serum albumin (BSA) for 5 minutes. The cell extracts in RIPA buffer plus phosphatase inhibitors were incubated with anti-FLAG M2 Affinity Gel (Sigma-Aldrich) for 3 hours at $4^{\circ} \mathrm{C}$. The beads were sequentially washed in RIPA buffer, then in heparitinase reaction buffer (20 mM Tris, $150 \mathrm{mM} \mathrm{NaCl}, 1 \mathrm{mM} \mathrm{MgCl}, 1 \mathrm{mM} \mathrm{Ca}$ $\mathrm{Cl}_{2}$, $\mathrm{pH}$ 7.4). The beads were then treated with heparitinase and chondroitinase $\mathrm{ABC}$ for 3 hours at $37^{\circ} \mathrm{C}$. The bound material was eluted with protein loading buffer and assessed by Western blot analysis for total Met, phospho-Met and glypican-1 or exposed to a phosphorimager to detect $\left[{ }^{125} \mathrm{I}\right] \mathrm{HGF}$.

\section{Biotin labeling and precipitation of biotin-labeled proteins}

Biotin labeling was conducted as previously described [43]. Equal amounts of protein $(100 \mu \mathrm{g})$ obtained from previously biotinylated cell extracts were precipitated for 2 hours at $4^{\circ} \mathrm{C}$ using streptavidin agarose resin (Thermo Fisher Scientific, Rockford, IL, USA). The bound material was eluted with protein loading buffer and assessed by Western blot analysis for total Met as described above.

\section{Transwell migration assays}

Migration assays were conducted using 24-well, 8- $\mu \mathrm{m}$-pore transwell systems (EMD Millipore). C2C12 and C6 myoblasts were seeded onto the upper part of the chamber at a density of 100,000 cells per well in $300 \mu \mathrm{l}$ of serum-free media. The lower chamber was loaded with $500 \mu \mathrm{l}$ of serum-free media with or without $20 \mathrm{ng} / \mathrm{ml} \mathrm{HGF}$ or $10 \%$ fetal bovine serum (FBS) (data not shown). The cells were allowed to migrate for 8 hours. Migration was assessed by removing the cells on the upper side of the transwell with a cotton swab, then staining the remaining cells with crystal violet, and solubilizing the cells in $1 \%$ Triton X-100 to measure the absorbance of the Triton X-100 solution at $595 \mathrm{~nm}[44]$.

\section{In vivo myoblast migration assay}

Myoblasts were labeled with the vital dialkylcarbocyanine dye DiI (red fluorescence) according to the supplier's protocol (Sigma-Aldrich). Aliquots containing $500 \times 10^{3}$ myoblasts were resuspended in $30 \mu \mathrm{l}$ of physiological serum and kept on ice. Immediately before grafting, $1 \mu \mathrm{l}$ of physiological serum containing or not containing $10 \mathrm{ng}$ of carrier-free HGF was added to myoblast. Three-monthold C57BL/10 mice were used as hosts, and cells were slowly injected longitudinally in both tibialis anterior (TA) muscles of mice under isoflurane gas anesthesia. Cells 
treated or not treated with HGF were injected into the contralateral TA muscles. After 7 days, the TA muscles were snap-frozen in isopentane before being entirely cut in transversal 7- $\mu \mathrm{m}$ cross-sections. Muscle cross-sections were visualized under a Nikon Diaphot inverted microscope (Nikon Instruments, Melville, NY, USA) equipped for epifluorescence. Concentric rings disposed $200 \mu \mathrm{m}$ from each other were superimposed on the selected muscle cross-section photographs. The total number of migrating myoblasts was determined by counting the labeled cells that had migrated more than $200 \mu \mathrm{m}$ from the injection site (which was determined by the border of the more intense fluorescence) [45]. The percentage of cells that reached more than $600 \mu \mathrm{m}$ over the total migrating myoblast was quantified. These percentages were used to compare the migration of myoblasts between the different conditions. All mice had free access to water and a chow diet until they were studied. All protocols were conducted in strict accordance with the formal approval of the Animal Ethics Committee of the Pontificia Universidad Católica de Chile.

Hepatocyte growth factor affinity labeling and binding assay Carrier-free HFG was radiolabeled with $\mathrm{Na}^{125}$ I using the chloramine $\mathrm{T}$ method as previously described for FGF-2 [38]. The biological activity of the radiolabeled HGF was determined by its ability to induce phosphorylation of ERK1/2 compared to unlabeled HGF as described above. The binding of $\left[{ }^{125} \mathrm{I}\right] \mathrm{HGF}$ to cell surfaces was performed as described previously with some modifications [46]. Briefly, subconfluent myoblasts were incubated for 2 hours at $4^{\circ} \mathrm{C}$ in DMEM containing $0.2 \%$ BSA, $25 \mathrm{mM}$ 2-[4-(2hydroxyethyl)piperazin-1-yl]ethanesulfonic acid (HEPES), $\mathrm{pH} 7.4$, and $10 \mathrm{ng} / \mathrm{ml}\left[{ }^{125} \mathrm{I}\right] \mathrm{HGF}$. To determine nonspecific binding, parallel cultures were incubated under the same conditions with the addition of a 200-fold excess of unlabeled HGF. After several washes in binding buffer and once with phosphate-buffered saline to remove unbound ligand, the cells were sequentially washed twice with $2 \mathrm{M}$ $\mathrm{NaCl}$ in $20 \mathrm{mM}$ HEPES, pH 7.4, for 5 minutes (low affinity binding) and twice with $2 \mathrm{M} \mathrm{NaCl}$ in $20 \mathrm{mM} \mathrm{NaAc}$, $\mathrm{pH}$ 4.0, for 5 minutes (high-affinity binding) [47-49]. The cells were extracted, and the protein content was determined as indicated below. The amount of radioactivity present in the low- and high-affinity washes and cell extracts was determined using a $\gamma$ scintillation counter. The counts per minute $(\mathrm{cpm})$ values were corrected for the protein content in the cell extracts.

\section{Protein determination}

Protein content in cell extracts was determined with a bicinchoninic acid protein assay kit (Pierce Biotechnology) with BSA used as the standard according to the supplier's protocol.

\section{Statistical analyses}

The number of replicates is indicated in the figure legends for each experiment. Data are presented as the mean \pm standard deviation. Statistical significance was assessed using two-way analysis of variance and a Bonferroni multiple-comparisons posttest. Differences were considered statistically significant at $P<0.05$.

\section{Results}

\section{Myoblasts require glypican-1 expression for proper hepatocyte growth factor signaling}

To evaluate the role of glypican-1 in the myoblast response to HGF, C2C12 myoblasts and the derived clone C6, which expresses low levels of HSPG [38], were treated with increasing concentrations of HGF. Phosphorylation of the Met receptor (phospho-Met) and the second messengers AKT (phospho-AKT) and ERK1/2 (phospho-ERK1/2) in response to HGF were analyzed by Western immunoblotting. Figure $1 \mathrm{~A}$ shows that the phosphorylation levels of Met, AKT and ERK1/2 increased in a HGF concentrationdependent manner. However, glypican-1-deficient myoblasts required higher concentrations of HGF to induce phosphorylation of the same proteins. The diminished response to HGF in the absence of glypican-1 was specific, because glypican-1 reexpression resulted in the rescue of HGF sensitivity. The same figure comparing wild-type (WT), glypican-1-deficient and glypican-1-overexpressing myoblasts also shows that the total levels of Met, AKT and ERK1/2 were not affected by the different conditions of glypican-1 expression. Quantification values from three independent experiments are shown in Figure 1B. Figure 1C shows that expression levels of Met present at the cell surface were unaltered by the presence or absence of glypican-1, as determined by labeling of the extracellular proteins with biotin followed by precipitation with streptavidin-agarose and detection with a specific antiMet receptor antibody using Western blots.

Because muscle precursor cells migrate in response to HGF during skeletal muscle development and regeneration, we decided to evaluate the role of glypican-1 in HGFdependent migration. Figures $2 \mathrm{~A}$ and $2 \mathrm{~B}$ show that HGF induces the migration of WT myoblasts tenfold. In contrast, less than twofold induction was found in glypican-1deficient myoblasts. In the absence of HGF, WT and glypican-1-deficient myoblast migration was essentially the same. Together, these results suggest that glypican-1 is required for a proper myoblast response to HGF, as determined by activation of HGF-dependent signaling and myoblast migration.

\section{Met is localized and activated in lipid rafts by a HGF- and glypican-1-dependent mechanism}

We have shown that glypican-1 was the only HSPG associated with lipid raft microdomains in myoblasts [38]. 


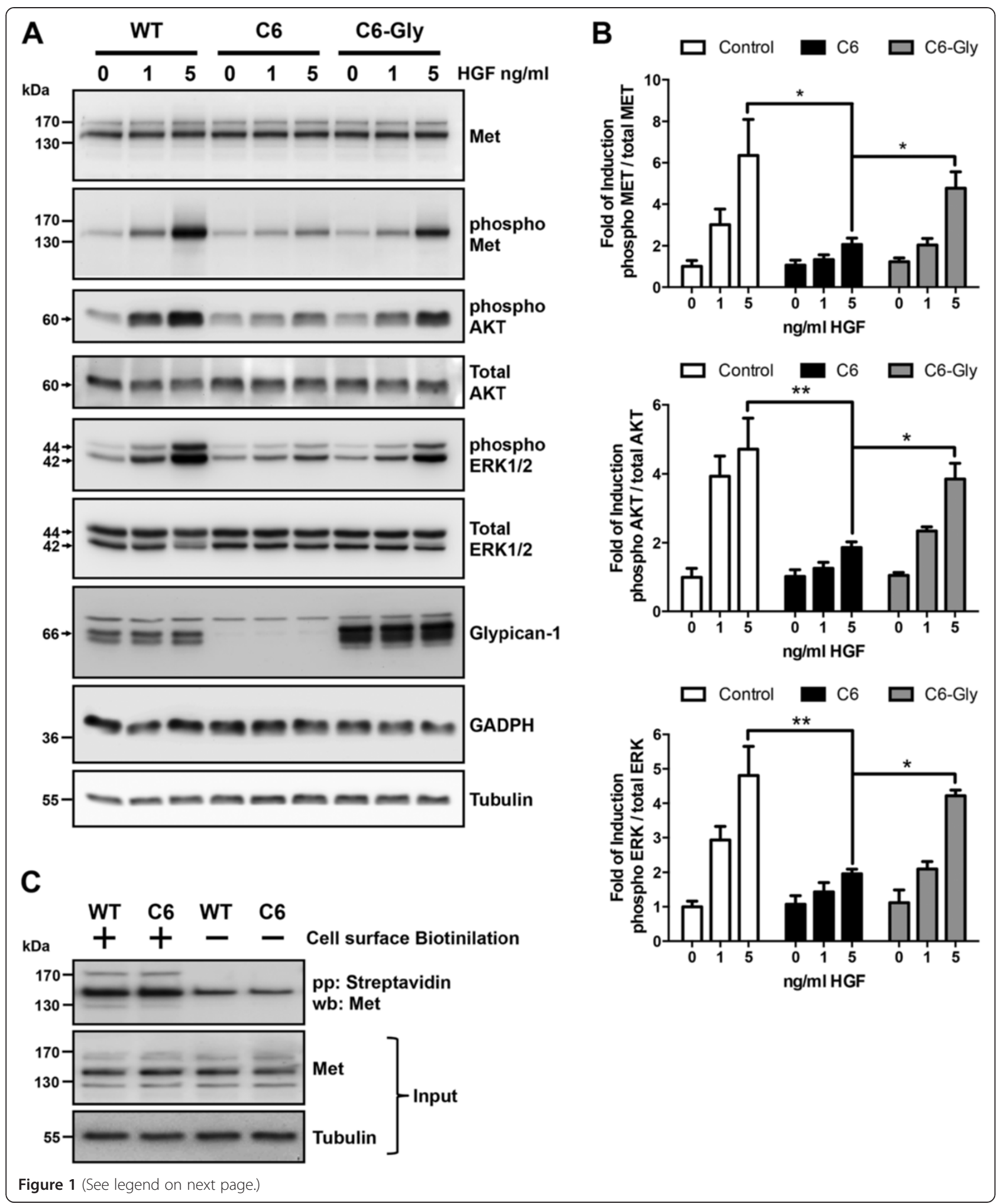


(See figure on previous page.)

Figure 1 Myoblasts require glypican-1 expression for proper hepatocyte growth factor signaling. (A) Wild-type (WT) C2C12 myoblasts and C6 myoblasts (glypican-1-deficient clone) transiently transfected with rat glypican-1 (C6-Gly), were serum-starved for 6 hours and then treated with the indicated concentrations of hepatocyte growth factor (HGF) for 5 minutes. The cell extracts were analyzed by immunoblotting for total HGF receptor (Met) levels, phospho-Met (Tyr 1235/1349), phospho- and total AKT levels, phospho- and total levels of extracellular signal-regulated kinases 1 and 2 (ERK1/2), glypican-1 core protein (after heparitinase treatment), glyceraldehyde 3-phosphate dehydrogenase (GAPDH) and tubulin. Total Met, AKT and ERK1/2 were used as loading control of its respective phosphorylated forms. GADPH and tubulin were used as loading control of glypican-1 expression levels. The Western blot images are representative of three independent experiments. (B) Quantitation of phospho-Met, phospho-AKT and phospho-ERK1/2 from three independent experiments is shown. Values are expressed as mean \pm standard deviation. Statistical significance was assessed using two-way analysis of variance and a Bonferroni multiple-comparisons posttest. ${ }^{*} P<0.05$, ${ }^{* *} P<0.01$. (C) Cell surface proteins of WT and C6 myoblasts labeled with EZ-Link Sulfo-NHS-Biotin (Pierce Biotechnology) as described in Methods. Aliquots of the cell extracts containing equal amounts of protein were precipitated with streptavidin-sepharose beads. The bound material was analyzed by Western blot immunoblotting against total Met. Aliquots of each assay obtained prior to the precipitation were analyzed by Western blot immunoassay for total Met, with tubulin used as the input control. Molecular weight standards are shown at left.

The results presented in Figures 1 and 2 suggest that glypican-1 acts as a positive regulator of HGF signaling. Therefore, we studied the association of Met with lipid raft membrane domains and the possible role of glypican-1 and HFG in this localization. To accomplish this objective, WT and glypican-1-deficient myoblasts were either untreated or treated with $10 \mathrm{ng} / \mathrm{ml} \mathrm{HGF}$, then fractionated in sucrose density gradients. Figure 3 shows that in untreated WT myoblasts (control), Met fractionated in lipid rafts (fractions 5, 6 and 7) and non-lipid-raft fractions (fractions 10, 11 and 12) to almost the same extent. In contrast, in glypican-1-deficient myoblasts, almost all Met fractionated in the non-lipid-raft fractions. In both WT and glypican-1deficient myoblasts, the basal phosphorylation level of Met (as shown in Figure 1) was exclusively present in nonlipid-raft fractions. The distributions of caveolin 1 and sodium/potassium ATPase $\left(\mathrm{Na}^{+} / \mathrm{K}^{+}\right.$-ATPase) were used as lipid raft and non-lipid-raft markers, respectively. These results suggest that glypican- 1 is required to distribute part of the total HGF receptor to lipid raft domains. After the treatment with HGF, the proportion of total Met in lipid rafts vs. non-lipid rafts was augmented in WT myoblasts, but not in glypican-1-deficient myoblasts. Importantly, in WT myoblasts, most of the phospho-Met was associated with lipid raft fractions. In contrast, in the glypican-1deficient myoblasts, most of the phospho-Met was associated with non-lipid-raft fractions. In both WT and glypican-1-deficient myoblasts, phospho-ERK1/2 and phospho-AKT were found in the non-lipid-raft fractions.

Next, we evaluated the presence of CD44 in lipid raft domains and its dependence on glypican-1. Our results show that the association of CD44 with the lipid raft domain is dependent on glypican expression and that this association is stabilized after pretreatment with HGF (Figure 3).

The results described above suggest that glypican- 1 is required for the translocation and stabilization of Met to lipid rafts, where it is activated. To test this possibility, cells were treated with $\mathrm{M} \beta \mathrm{CD}$, an antifungal drug that selectively extracts cholesterol from the plasma membrane to disrupt lipid raft structure. WT myoblasts pretreated with $\mathrm{M} \beta \mathrm{DC}$ at two different concentrations ( $1 \mathrm{nM}$ and 10 $\mathrm{nM}$ ) were stimulated with increasing concentrations of HGF for 5 minutes. Figure 4A shows that total Met levels did not change significantly after treatment, but the HGFdependent activation of AKT and ERK was diminished in myoblasts with disrupted lipid raft domains. In addition, Figure 4B shows that both Met and caveolin 1 were relocalized from lipid rafts to non-lipid-raft fractions after $\mathrm{M} \beta \mathrm{CD}$ treatment.

The results of the present study indicate that Met, phospho-Met and glypican-1 colocalized in lipid raft domains of the plasma membrane. Moreover, glypican-1 expression and lipid raft integrity were required to sustain the HGF-dependent signaling. Next, we evaluated whether glypican-1 per se or its presence in lipid raft domains was required to sustain the HGF signaling mediated by the Met receptor. A chimeric form of HSPG containing the extracellular domain of rat glypican- 1 and the transmembrane and cytoplasmic domains of mouse syndecan1 (F-GlySyn) was expressed in WT cells. This chimeric form localized in the non-lipid-raft region of the plasma membrane as we previously reported [38]. Figure 5 shows that mock-transfected WT myoblasts induced the activation of AKT and ERK1/2 in response to HGF. In myoblasts expressing the chimeric F-GlySyn, however, both phospho-AKT and phospho-ERK1/2 levels decreased compared to WT cells. These levels are comparable to levels found in the glypican-1-deficient myoblasts. The figure also shows that diminished sensitivity to HGF, which we had previously observed in the glypican-1-deficient cells, was restored after reexpressing glypican-1 by transient transfection with rat glypican-1. Together, these results indicate that glypican-1 must be associated with lipid rafts to sustain HGF-dependent signaling.

\section{Glypican-1 physically interacts with HGF and Met in lipid rafts to form an active signaling complex}

The results described above suggest that glypican-1 may interact with Met and HGF in lipid rafts to form the 


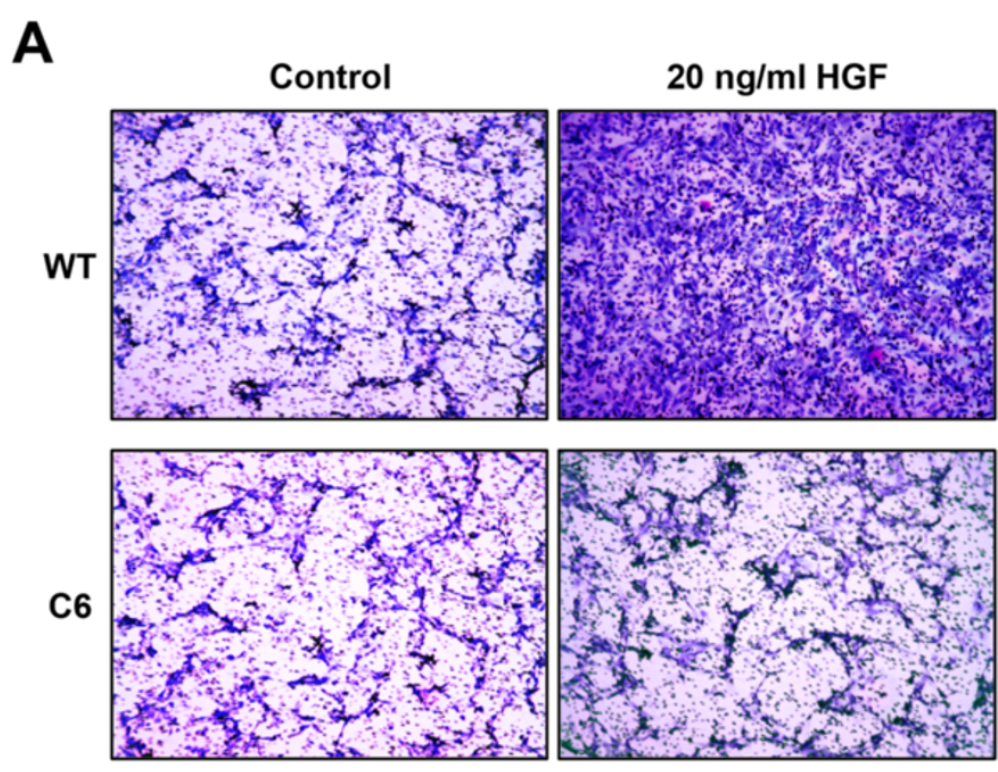

B

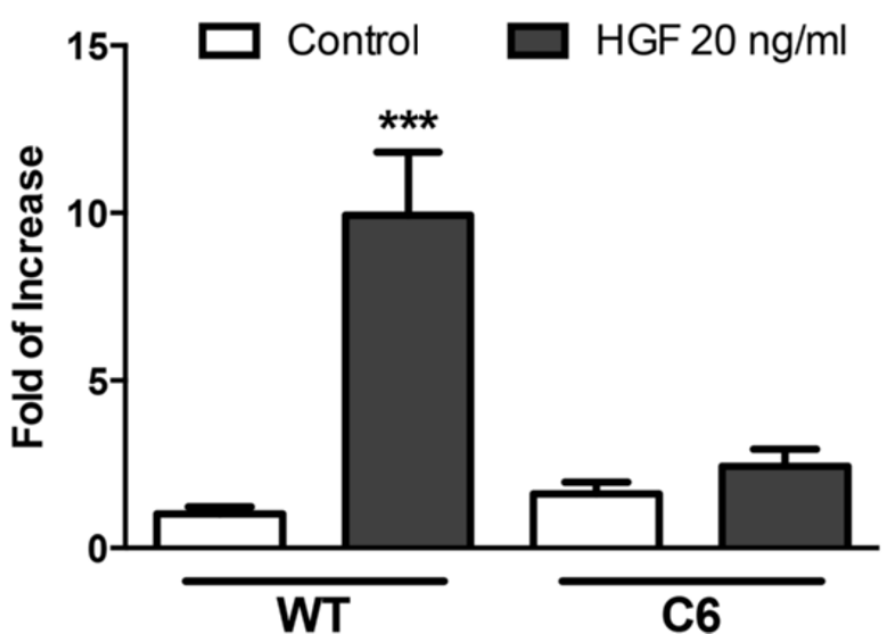

Figure 2 Hepatocyte growth factor-dependent myoblast migration requires glypican-1 expression. (A) Wild-type (WT) C2C12 and C6 myoblasts were seeded onto the upper part of transwell chambers at the same density in serum-free media. The lower chamber contained serum-free media with or without $20 \mathrm{ng} / \mathrm{ml}$ hepatocyte growth factor (HGF). After 8 hours, the cells in the upper part of the filter were scraped. The cells that had efficiently migrated through the filter were fixed with paraformaldehyde, stained with crystal violet and photographed or as shown in (B) stained with crystal violet and solubilized in phosphate-buffered saline containing 1\% Triton X-100. The absorbance of the detergent soluble fraction at $595 \mathrm{~nm}$ was determined. Values are expressed as mean \pm standard deviation of three independent experiments. ${ }^{* * *} P<0.001$ relative to WT control. The migration of WT under control conditions corresponds to a value of 1.0.

ternary complex Met-HGF-glypican-1. To test this possibility, WT myoblasts were transfected with an empty vector as the control or with rat glypican-1 (F-Gly) or chimeric FGlySyn, both of which contained a FLAG epitope. Fortyeight hours later, the cells were incubated with or without $20 \mathrm{ng} / \mathrm{ml}\left[{ }^{125} \mathrm{I}\right]$ HGF for 5 minutes. The cell extracts in the presence of phosphatase inhibitors were immunoprecipitated with anti-FLAG antibodies, and the precipitate was evaluated for total and phospho-Met. Figure 6A shows that, in the absence of HGF, Met coimmunoprecipitated with both F-Gly and F-GlySyn almost to the same extent. When the cells were treated with HGF, the levels of coimmunoprecipitated Met increased with both forms of glypican-1, though in a more pronounced way with F-Gly. Interestingly, when the activated form of precipitated Met was evaluated, F-Gly interacted substantially more than the non-lipid-raft form of glypican-1 (F-GlySyn) with phosphoMet. We also found that $\left[{ }^{125} \mathrm{I}\right] \mathrm{HGF}$ coimmunoprecipitated almost four times more with F-Gly than with F-GlySyn. As an immunoprecipitation control, F-Gly and F-GlySyn were detected with specific anti-glypican-1 antibodies. These results suggested that glypican-1 physically interacted with 

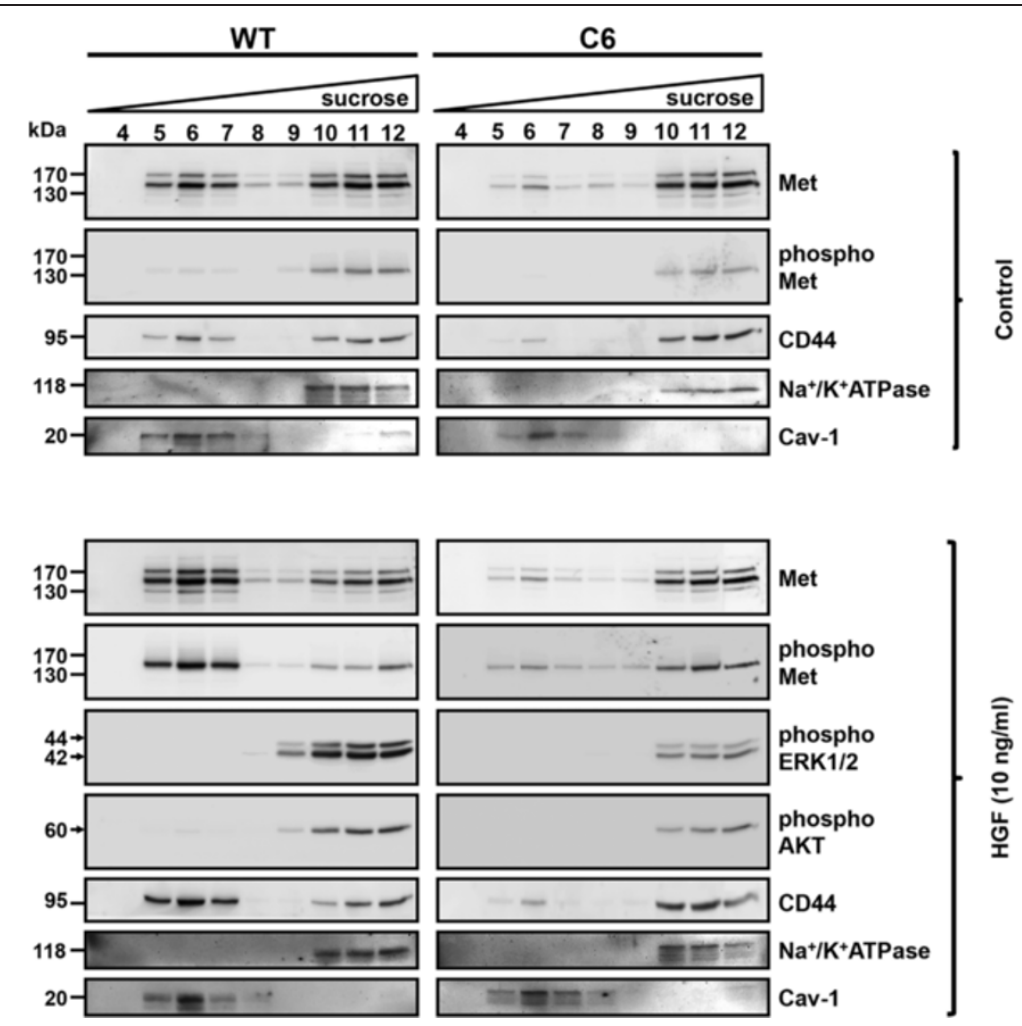

Figure 3 Met is localized and activated by hepatocyte growth factor in lipid rafts by a glypican-1-dependent mechanism. C2C12 and C6 myoblasts were serum-starved for 6 hours and then treated without (control) or with $10 \mathrm{ng} / \mathrm{ml}$ hepatocyte growth factor (HGF) for 5 minutes. The cells were lysed with 1\% Triton X-100 and fractionated by sucrose density gradients (5\% to 45\%). Twelve fractions were collected, but only the last ten fractions were analyzed (the lipid raft-enriched fraction started at fraction 4) by immunoblotting for total HGF receptor (Met), phospho-Met (Tyr 1235/1349), phosphorylated extracellular signal-regulated kinases 1 and 2 (phospho-ERK1/2), phospho-AKT and CD44. As fractionation controls, the presence of the lipid raft membrane protein marker caveolin 1 (Cav 1) and the non-lipid-raft domain marker $\mathrm{Na}^{+} / \mathrm{K}^{+}$-ATPase are shown. WT, Wild type.

Met and HGF preferentially located in lipid rafts, where the receptor was stabilized and activated in response to HGF. To determine if binding of HGF on the myoblast cell surface was modulated by glypican-1, we performed a ligand binding assay. WT and glypican-1-deficient myoblasts were incubated with $\left[{ }^{125} \mathrm{I}\right] \mathrm{HGF}$ at $4{ }^{\circ} \mathrm{C}$ to avoid endocytosis of the ligand. The radioactivity associated with low- and highaffinity binding sites, as well as the remaining radioactivity in the cell extracts, was determined. Figure 6B shows that the binding of $\left[{ }^{125} \mathrm{I}\right] \mathrm{HGF}$ to both low- and high-affinity binding sites was diminished by $50 \%$ in the absence of glypican-1, suggesting that this lipid raft-associated HSPG was required to concentrate HGF on the cell surface and for binding to Met. These results indicate that glypican-1 facilitated the binding of HGF to the Met receptor, enhancing its phosphorylation at lipid raft domains.

\section{Migration of transplanted myoblasts in skeletal muscles is} enhanced by HGF and requires glypican-1

The data described above demonstrates the requirement of glypican-1 for HGF-dependent signaling and migration. To test the in vivo role of glypican-1 on HGF-induced myoblast migration, we subjected the $\mathrm{C} 57 \mathrm{BL} / 10$ mice to intramuscular coinjection of $\mathrm{C} 2 \mathrm{C} 12$ or $\mathrm{C} 6$ myoblasts together with HGF in the TA muscles. Seven days after the transplantation, the muscles were extracted, frozen in liquid nitrogen and cryosectioned. Prior to grafting, the myoblasts were stained with the vital dialkylcarbocyanine dye, DiI (red fluorescence), to trace their localization in the muscle cryosections. Figure 7 shows that HGF induced an increase in the number of WT myoblasts that migrated longer distances (more than $600 \mu \mathrm{m}$ ). However, this effect was prevented in glypican-1-deficient myoblasts. These results suggest that glypican-1 expression is required for efficient in vivo myoblast migration in response to HGF.

\section{Discussion}

One of the main functions of membrane-associated HSPGs, particularly for glypicans, is to regulate signaling of several cytokines, morphogens and growth factors [38,50-53]. It has been reported that loss of HSPG expression prevents the cell mitogenic response induced by HGF [54-56], but the specific roles and mechanisms of the different HSPGs 


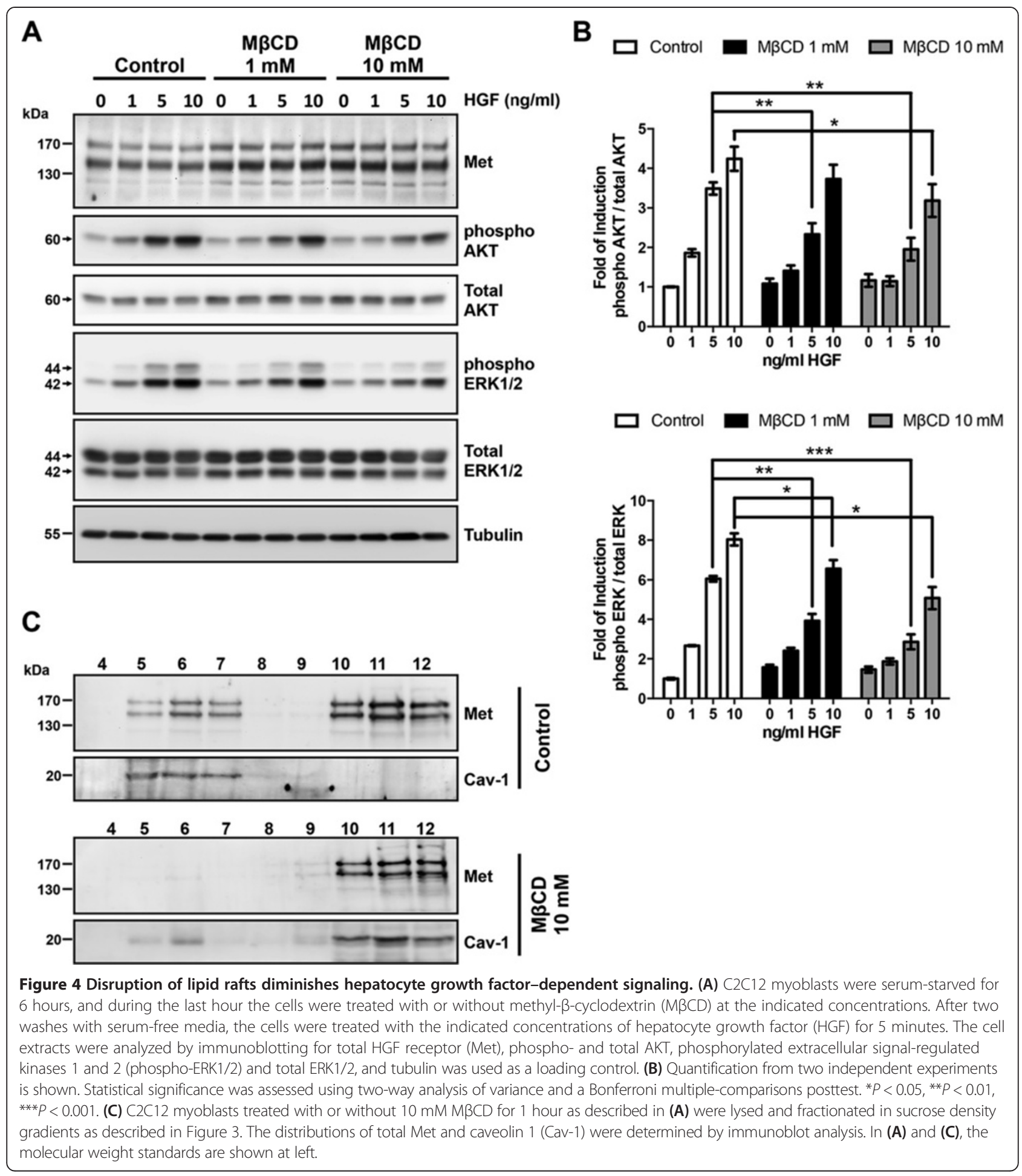

as regulators of HGF-dependent responses have not been studied in depth.

In the present report, we show that, in myoblasts, glypican-1 located in lipid raft membrane domains was required for maximum HGF-dependent signaling and cell migration in vitro and in vivo. We also show that glypican-
1 appears as an essential cell-surface, low-affinity binding site for HGF, likely acting as a presenter or facilitator of HGF to its high-affinity Met binding site, where it is cofractionated with the known HGF coreceptor CD44 [34]. Glypican-1, Met and HGF formed an active signaling ternary complex in lipid raft membrane domains. Whether 


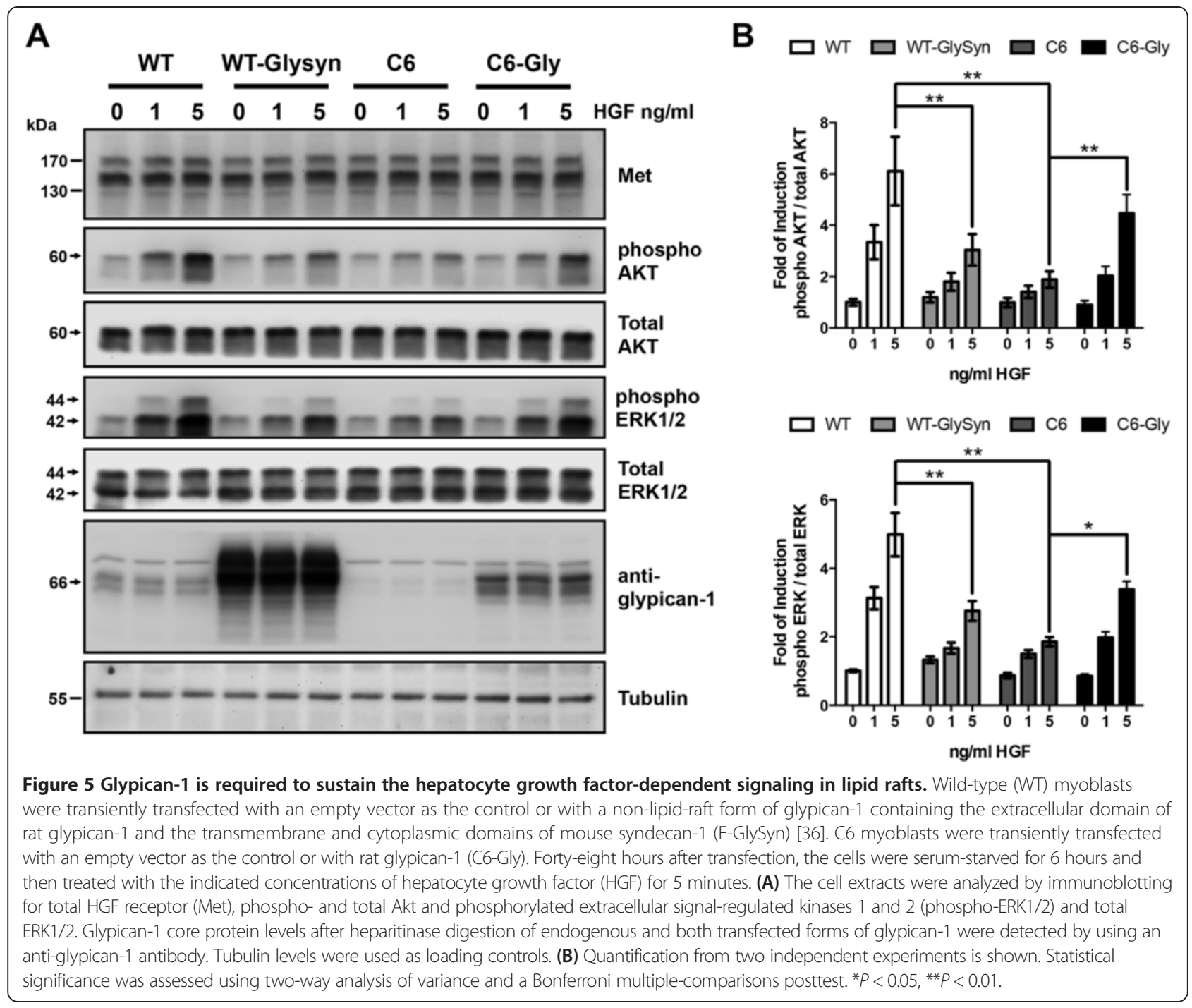

phospho-Met is relocated from non-lipid-raft to lipid raft domains in response to HGF or whether Met is directly activated in lipid rafts, where it is stabilized, are still not known. Chimeric non-lipid-raft glypican-1 (F-GlySyn) also coimmunoprecipitated with Met, but not with the active form of the receptor or with HGF, indicating that localization of glypican-1 in lipid raft domains was unnecessary for the interaction between Met and the extracellular part of glypican-1, but was required for binding of HGF and subsequent receptor activation.

The participation of lipid rafts as signaling platforms to facilitate interaction of the required elements to activate a signaling pathway has been reported for different receptor tyrosine kinases, such as the platelet-derived growth factor, TrkA/nerve growth factor and insulin receptors. After ligand activation, MAPK and phosphoinositide 3-kinase (PI3K) signaling mediators are recruited to lipid rafts, where they are activated [57-60]. The same mechanism of action has also been reported for $G$ protein-coupled receptors, including $\beta$-adrenergic, neurokinin 1 receptor and muscarinic cholinergic receptors [61-64]. Lipid rafts can also act as a platform where receptor signaling is turned off, such as in the case of serinethreonine kinase transforming growth factor $\beta$ [65] and tyrosine kinase epidermal growth factor receptors, which are activated in lipid rafts, but rapidly relocalized to nonlipid rafts to de-activate downstream signaling [66]. We previously reported that glypican-1 in lipid rafts acted as a negative regulator of FGF-2 signaling, sequestering the growth factor in these domains away from their transducing receptors [38]. Our present results show that, upon ligand binding, Met is recruited to lipid rafts to activate MAPK, ERK1/2 and PI3K/AKT pathways. This process required the presence of structured lipid raft membrane domains as well as glypican-1 in these domains to sustain the HGF-dependent signaling. However, these results did not eliminate the possibility of other Met-dependent functions in non-lipid rafts. 


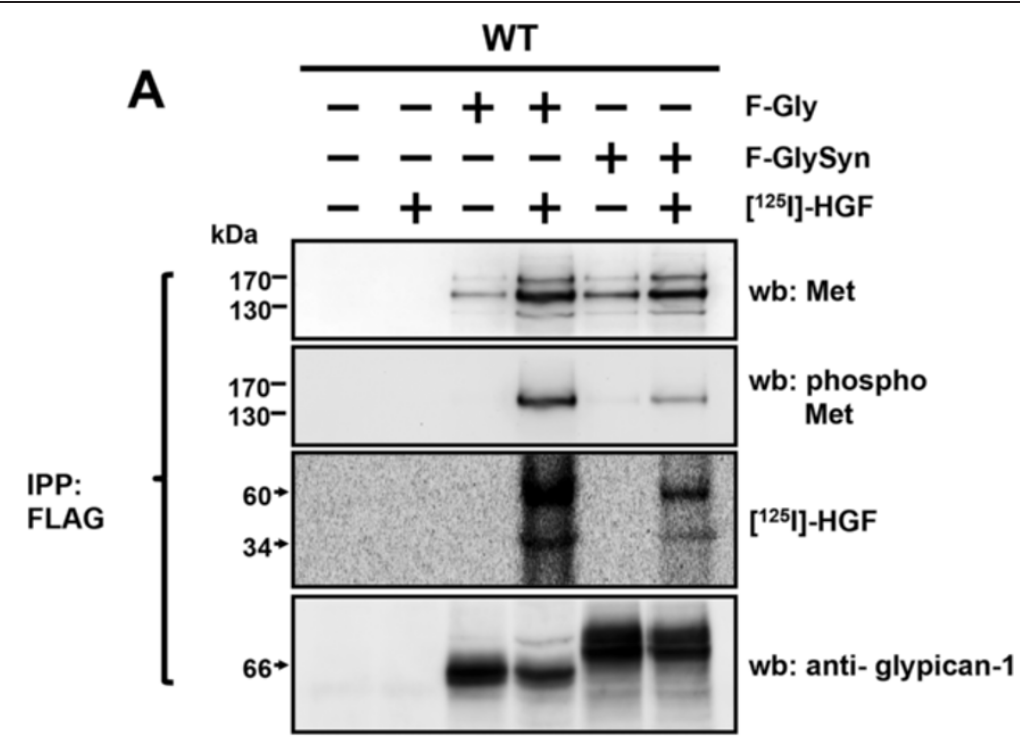

B

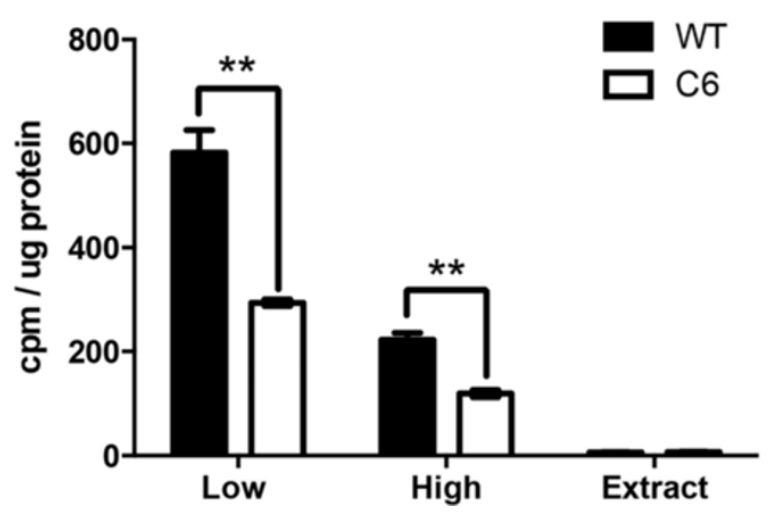

Figure 6 Glypican-1 in lipid rafts coimmunoprecipitates with the activated form of Met and regulates hepatocyte growth factor binding to low- and high-affinity cell surface binding sites. (A) C2C12 myoblasts were transfected with rat glypican-1 (F-Gly) or the non-lipid-raft chimeric glypican-1 (F-GlySyn), as described in the Figure 5 legend. F-Gly and F-GlySyn contained a FLAG epitope at the amino terminus. Forty-eight hours after transfection, the cells were serum-starved for 4 hours and then treated with or without $20 \mathrm{ng} / \mathrm{ml}\left[{ }^{125}\right.$ l] HGF for 5 minutes. The cell extracts were incubated with anti-FLAG M2 Affinity Gel for 3 hours at $4^{\circ} \mathrm{C}$, and, after several washes, the beads were incubated with heparitinase and chondroitinase ABC for 8 hours. The immunoprecipitated (IPP) bound material was eluted with protein loading buffer and analyzed by Western immunoblotting for total hepatocyte growth factor (HGF) receptor (Met), phospho-Met and glypican-1. The membranes were exposed to a phosphorimager to detect [25] HGF. (B) C2C12 and C6 myoblasts were serum-starved for 4 hours and then treated with or without $10 \mathrm{ng} / \mathrm{ml}\left[{ }^{125} \mathrm{l}\right] \mathrm{HGF}$ for 2 hours at $4^{\circ} \mathrm{C}$. After several washes in ice-cold binding buffer, $\left[{ }^{125} \mathrm{l}\right] \mathrm{HGF}$ was eluted with high salt and acid to determine low- and high-affinity binding sites, respectively. Counts per minute (cpm) were determined by $y$ counting and corrected for protein content in cell extracts. Statistical significance was assessed by two-way analysis of variance and a Bonferroni multiple comparisons posttest. ${ }^{* *} P<0.01$.

HGF is involved in many different processes in which both cell growth and cell migration are required, such as in embryonic development, tissue repair and organ regeneration [67]. In particular, the roles of HGF and Met for muscle development, differentiation and regeneration have been reported [7]. During limb muscle development, migratory muscle precursor cells delaminate from the dermomyotome, an epithelial structure that develops from somites, reaching their specific destination in the limb buds [68-70] in a process dependent on HGF and
Met expression [6-8]. In the present study, we show that glypican-1 was required for the migration of myoblasts in response to HGF, both in vitro and in vivo. In vitro glypican-1-deficient myoblasts were almost unresponsive to HGF as a chemoattractant in the Boyden chamber assays, in contrast to WT myoblasts, which migrated extensively through the membrane toward the HGF-containing media. The migration capacity toward other chemoattractants did not appear hampered, because no significant differences were observed when both types of cells were 


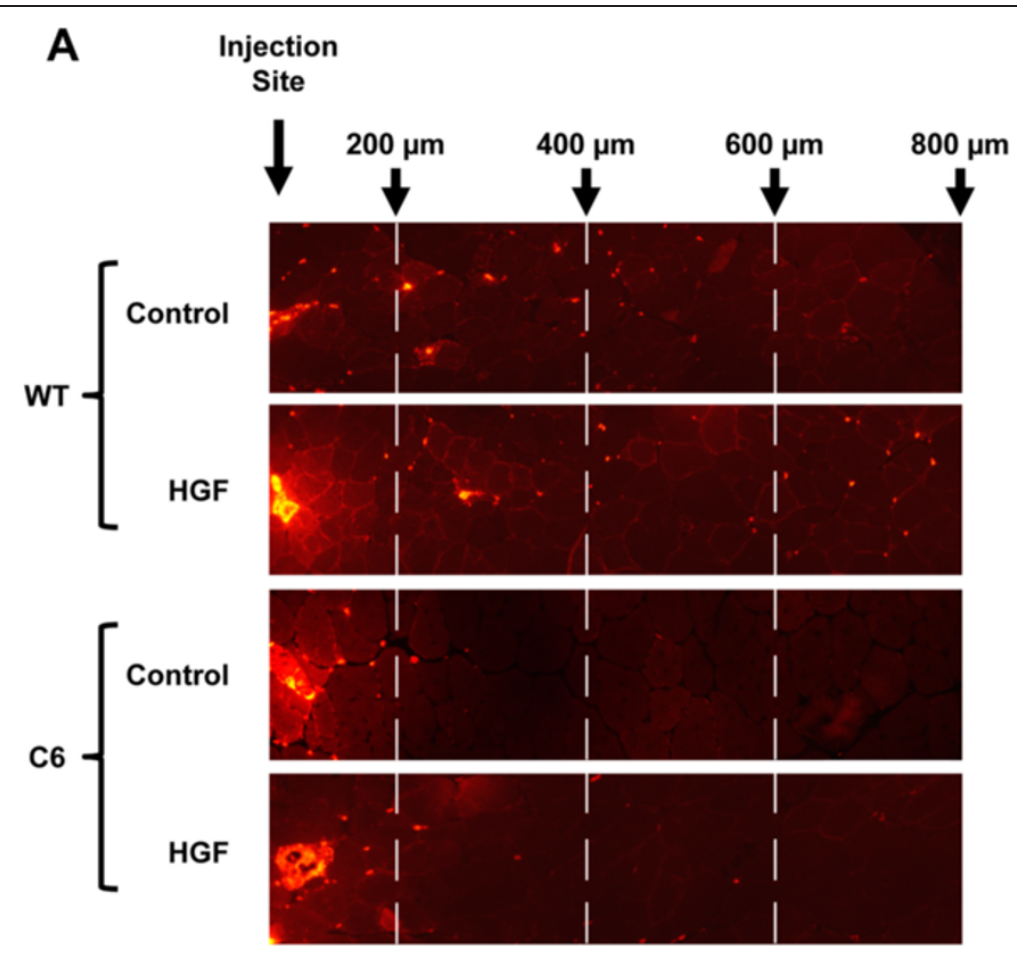

B

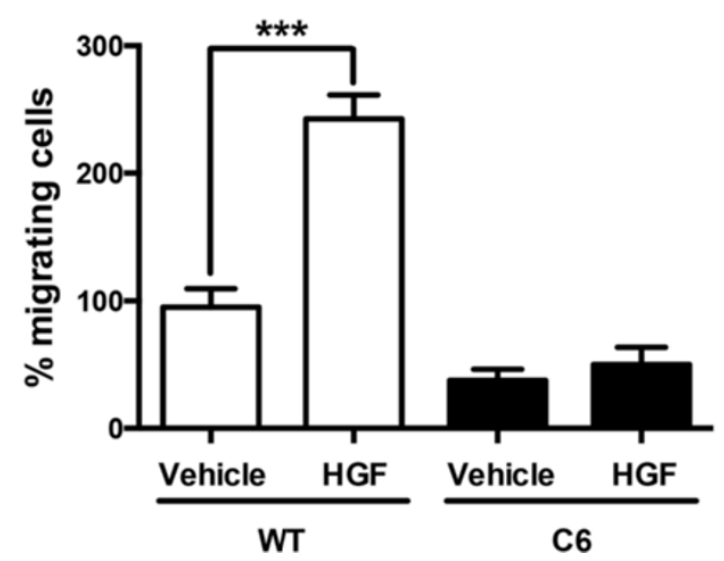

Figure 7 Hepatocyte growth factor-dependent migration of myoblast in vivo requires glypican-1 expression. (A) Wild-type (WT) or C6 myoblasts $\left(500 \times 10^{3}\right)$, prelabeled with the vital dialkylcarbocyanine dye, Dil (red fluorescence), and suspended in $30 \mu l$ of physiological serum with or without $10 \mathrm{ng}$ of carrier-free hepatocyte growth factor (HGF) were transplanted into the left and right tibialis anterior (TA) muscles, respectively, of 3-month-old C57BL/10 mice under anesthesia. One week later, both TA muscles were processed for cryosectioning. Concentric circles with annuli 200 Mm from each other were superimposed on selected muscle cross-section images. The cells were counted under an inverted microscope equipped for epifluorescence. (B) The number of the cells that migrated more than $200 \mu \mathrm{m}$ were considered the total migrating cells, and the percentages of cells that migrated more than $600 \mu \mathrm{m}$ were calculated. The migration of untreated WT myoblasts was corrected to $100 \%$. Values are expressed as mean \pm SD of two independent experiments. ${ }^{* *} P<0.001$.

challenged to migrate toward 10\% FBS (data not shown). We determined the role of glypican-1 in myoblast migration in vivo in response to HGF by intramuscular coinjection of WT or glypican-1-deficient myoblasts in the presence or absence of the growth factor. In vivo myoblast migration was improved by coinjection with HGF, particularly in WT cells, compared to the slight migratory effect observed with glypican-1-deficient myoblasts. These results show that in vivo migration of myoblast expanded in vitro could be improved by coinjection with HGF. In addition, this effect required the expression of glypican-1 in the myoblast plasma membrane.

This result is very promising, because one of the main problems associated with stem cell therapies for the treatment of patients with muscular dystrophies is the poor migration of the transplanted cells. As a result, therapy with intramuscular injection of myoblasts or SCs in several clinical trials has been mostly unsuccessful [71-73]. 
Based upon our results, the use of fluorescence-activated cell sorting with higher expression of glypican-1 and/or coinjection with HGF to improve efficiency needs to be carefully evaluated.

As previously mentioned, HSPGs are essential components required for the myogenic inhibitory signaling of FGF-2 [28,30-33,74-76] and HGF [3,77,78]. During differentiation, expression of all syndecans was downregulated, which is consistent with a reduction in sensitivity to the inhibitory effect of FGF-2 [32,38,79]. In contrast, the expression of glypican-1 remained constant, being the main cell surface HSPG present during myogenesis $[35,39]$. In addition, during muscle regeneration, expression of glypican-1 increased and was temporarily and histologically related to the newly regenerating myofiber expression of embryonic myosin [80]. However, the exact role of glypican-1 during this process has not been addressed to date. Glypican-1-knockout mice were almost indistinguishable from WT mice in size, fertility, internal anatomy and lifespan, with the exception of the brain, which was noticeably smaller [81]. This suggests that glypican-1 is required in mammals for brain development, but not for other tissues, such as skeletal muscle. To further elucidate the results of the present study, it would be informative to evaluate the skeletal muscle regeneration process in glypican-1-null mice.

Glypican-1 is required for terminal myogenesis, acting as a repressor of FGF-2 [38]. This can be explained by the sequestration of FGF-2 by glypican-1 in lipid rafts, away from FGF-2 receptors and syndecans that are located in non-raft domains. As we have shown, however, glypican-1 positively regulates HGF-mediated signaling by recruiting or stabilizing Met in lipid raft domains where it was activated, with consequential triggering of downstream targets. Reduction of Met expression during the myogenic differentiation process (data not shown) [82] therefore seemed to circumvent the myogenic inhibitory effect of HGF in spite of the constitutive expression of glypican-1 [35,39]. All of these changes switched the balance from a proliferative, migratory and antimyogenic state in response to FGF-2 and HGF to a promyogenic response whereby both muscle inhibitory signals decreased, thus allowing differentiation.

Immediately after injury, low concentrations of HGF ( 2 to $3 \mathrm{ng} / \mathrm{ml}$ ) are released from ECM reservoirs [83-85] in conjunction with the local release of nitric oxide. These are the first cues involved in the activation (that is, exit from quiescence) of SCs, which then proliferate to form new fibers or repair the destroyed ones $[10,84,86]$. To maintain their regenerative potential, many proliferating $\mathrm{SCs}$ return to quiescence, repopulating the SC niche to maintain a progenitor pool, which will be activated to repair the muscle in response to a new injury [87-89]. This capacity to repopulate the quiescent SC pool is one of main features of stem cells. It is explained by asymmetric cell division involving some daughter cells, which continue the differentiation pathway, whereas other cells exit the cell cycle and return to quiescence [90,91]. HGF concentrations above $20 \mathrm{ng} / \mathrm{ml}$ induced the quiescence of primary myogenic cells. This effect was reversible because treatment with low concentrations of HGF could rescue the proliferation of myogenic cells after high HGF-induced quiescence [77].

It would be interesting to determine whether glypican1 has a potential role in the control of SC sensitivity to extracellular HGF and to define which SCs will continue to form new muscle and which will exit the cell cycle in asymmetric cell division to maintain the pool of muscle stem cells. Besides its association with lipid rafts in the cell membrane, glypican-1 is also endogenously processed to a soluble form that is incorporated into the ECM $[35,38,80]$, where it can act as a reservoir for HGF and other heparin-binding growth factors that can be released upon an injury to activate SCs. More accurate future studies designed to determine the control mechanisms of glypican-1 and Met expression between daughter cells during asymmetric cell division, as well as the role of glypican1 during the muscle regeneration process, are therefore necessary.

\section{Conclusion}

Glypican-1 in lipid raft membrane domains is required for maximum HGF-dependent signaling and myoblast migration in vitro and in vivo.

\section{Abbreviations \\ AKT: Effector of the phosphoinositide 3-kinase/AKT pathway; ERK: Extracellular signal-regulated kinase; FGF-2: Fibroblast growth factor 2; FGFR: Transducing fibroblast growth factor receptor; F-Gly: Rat glypican-1 containing a FLAG epitope in its amino terminus; F-GlySyn: Chimeric heparan sulfate proteoglycan (extracellular domain of rat glypican-1 and the trans- membrane and cytoplasmic domains of mouse syndecan-1 containing a FLAG epitope); HGF: Hepatocyte growth factor; HS: Heparan sulfate; HSPG: Heparan sulfate proteoglycan; Met: Transducing hepatocyte growth factor receptor; MBCD: Methyl- $\beta$-cyclodextrin; $\mathrm{Na}^{+} / \mathrm{K}^{+}$-ATPase: Sodium potassium ATP pump; Phospho-AKT: Phosphorylated form of AKT; Phospho-ERK: Phosphorylated form of extracellular signal-regulated kinase; Phospho-Met: Phosphorylated form of hepatocyte growth factor receptor; TA: Tibialis anterior.}

\section{Competing interests}

The authors declare that they have no competing interests.

\section{Authors' contributions}

$J G$ participated in the design of the study, carried out the cellular and molecular experiments, performed the statistical analysis and drafted the manuscript. DC carried out the myoblast migration experiments. EB conceived the study, participated in its design and coordination and helped to draft the manuscript. All authors read and approved the final manuscript.

\section{Acknowledgments}

This study was supported by grants CARE-PFB-12/2007, CONICYT-79090027, FONDECYT-11110010 and 1110426 and by Fundación Chilena para Biología Celular Proyecto MF-100. 
Received: 6 October 2013 Accepted: 20 January 2014

Published: 12 February 2014

\section{References}

1. Ciciliot S, Schiaffino S: Regeneration of mammalian skeletal muscle: basic mechanisms and clinical implications. Curr Pharm Des 2010, 16:906-914.

2. Tedesco FS, Dellavalle A, Diaz-Manera J, Messina G, Cossu G: Repairing skeletal muscle: regenerative potential of skeletal muscle stem cells. J Clin Invest 2010, 120:11-19.

3. Gal-Levi R, Leshem Y, Aoki S, Nakamura T, Halevy O: Hepatocyte growth factor plays a dual role in regulating skeletal muscle satellite cell proliferation and differentiation. Biochim Biophys Acta 1998, 1402:39-51.

4. Stoker M, Gherardi E, Perryman M, Gray J: Scatter factor is a fibroblastderived modulator of epithelial cell mobility. Nature 1987, 327:239-242.

5. Naldini L, Weidner KM, Vigna E, Gaudino G, Bardelli A, Ponzetto C, Narsimhan RP, Hartmann G, Zarnegar R, Michalopoulos GK, Birchmeier W, Comoglio PM: Scatter factor and hepatocyte growth factor are indistinguishable ligands for the MET receptor. EMBO J 1991, 10:2867-2878.

6. Bladt F, Riethmacher D, Isenmann S, Aguzzi A, Birchmeier C: Essential role for the c-met receptor in the migration of myogenic precursor cells into the limb bud. Nature 1995, 376:768-771.

7. Birchmeier C, Bladt F, Yamaai T: The functions of HGF/SF and its receptor, the c-Met tyrosine kinase, in mammalian development. Ciba Found Symp 1997, 212:169-182

8. Birchmeier C, Gherardi E: Developmental roles of HGF/SF and its receptor, the c-Met tyrosine kinase. Trends Cell Biol 1998, 8:404-410.

9. Sheehan SM, Allen RE: Skeletal muscle satellite cell proliferation in response to members of the fibroblast growth factor family and hepatocyte growth factor. I Cell Physiol 1999, 181:499-506.

10. Sheehan SM, Tatsumi R, Temm-Grove CJ, Allen RE: HGF is an autocrine growth factor for skeletal muscle satellite cells in vitro. Muscle Nerve 2000, 23:239-245.

11. Sonnenberg E, Meyer D, Weidner KM, Birchmeier C: Scatter factor/ hepatocyte growth factor and its receptor, the c-met tyrosine kinase, can mediate a signal exchange between mesenchyme and epithelia during mouse development. J Cell Biol 1993, 123:223-235.

12. Sonnenberg E, Weidner KM, Birchmeier C: Expression of the met-receptor and its ligand, HGF-SF during mouse embryogenesis. EXS 1993, 65:381-394.

13. Jennische E, Ekberg S, Matejka GL: Expression of hepatocyte growth factor in growing and regenerating rat skeletal muscle. Am J Physiol 1993, 265:C122-C128

14. Sipeki S, Bander E, Buday L, Farkas G, Bácsy E, Ways DK, Faragó A: Phosphatidylinositol 3-kinase contributes to Erk1/Erk2 MAP kinase activation associated with hepatocyte growth factor-induced cell scattering. Cell Signal 1999, 11:885-890.

15. Zhang YW, Vande Woude GF: HGF/SF-met signaling in the control of branching morphogenesis and invasion. J Cell Biochem 2003, 88:408-417.

16. Goyal L, Muzumdar MD, Zhu AX: Targeting the HGF/c-MET pathway in hepatocellular carcinoma. Clin Cancer Res 2013, 19:2310-2318.

17. Ghatak S, Hascall VC, Markwald RR, Misra S: Stromal hyaluronan interaction with epithelial CD44 variants promotes prostate cancer invasiveness by augmenting expression and function of hepatocyte growth factor and androgen receptor. J Biol Chem 2010, 285:19821-19832.

18. Singleton PA, Salgia R, Moreno-Vinasco L, Moitra J, Sammani S, Mirzapoiazova T, Garcia JG: CD44 regulates hepatocyte growth factormediated vascular integrity: role of c-Met, Tiam1/Rac1, dynamin 2, and cortactin. J Biol Chem 2007, 282:30643-30657.

19. Seveau S, Bierne H, Giroux S, Prévost MC, Cossart P: Role of lipid rafts in E-cadherin- and HGF-R/Met-mediated entry of Listeria monocytogenes into host cells. J Cell Biol 2004, 166:743-753.

20. Hung CM, Kuo DH, Chou CH, Su YC, Ho CT, Way TD: Osthole suppresses hepatocyte growth factor (HGF)-induced epithelial-mesenchymal transition via repression of the c-Met/Akt/mTOR pathway in human breast cancer cells. J Agric Food Chem 2011, 59:9683-9690.

21. Orian-Rousseau V, Chen L, Sleeman JP, Herrlich P, Ponta H: CD44 is required for two consecutive steps in HGF/c-Met signaling. Genes Dev 2002, 16:3074-3086.

22. Knudson W, Chow G, Knudson CB: CD44-mediated uptake and degradation of hyaluronan. Matrix Biol 2002, 21:15-23.
23. Villena J, Brandan E: Dermatan sulfate exerts an enhanced growth factor response on skeletal muscle satellite cell proliferation and migration. J Cell Physiol 2004, 198:169-178.

24. Lyon M, Deakin JA, Mizuno K, Nakamura T, Gallagher JT: Interaction of hepatocyte growth factor with heparan sulfate: elucidation of the major heparan sulfate structural determinants. J Biol Chem 1994, 269:11216-11223.

25. Lyon M, Gallagher JT: Hepatocyte growth factor/scatter factor: a heparan sulphate-binding pleiotropic growth factor. Biochem Soc Trans 1994, 22:365-370.

26. Ashikari S, Habuchi H, Kimata K: Characterization of heparan sulfate oligosaccharides that bind to hepatocyte growth factor. J Biol Chem 1995, 270:29586-29593.

27. Catlow KR, Deakin JA, Wei Z, Delehedde M, Fernig DG, Gherardi E, Gallagher JT, Pavão MS, Lyon M: Interactions of hepatocyte growth factor/ scatter factor with various glycosaminoglycans reveal an important interplay between the presence of iduronate and sulfate density. J Biol Chem 2008, 283:5235-5248.

28. Bernfield M, Götte M, Park PW, Reizes O, Fitzgerald ML, Lincecum J, Zako M: Functions of cell surface heparan sulfate proteoglycans. Annu Rev Biochem 1999, 68:729-777.

29. Bernfield M, Hooper KC: Possible regulation of FGF activity by syndecan, an integral membrane heparan sulfate proteoglycan. Ann NY Acad Sci 1991, 638:182-194.

30. Yayon A, Klagsbrun M, Esko JD, Leder P, Ornitz DM: Cell surface, heparinlike molecules are required for binding of basic fibroblast growth factor to its high affinity receptor. Cell 1991, 64:841-848.

31. Larraín J, Carey DJ, Brandan E: Syndecan-1 expression inhibits myoblast differentiation through a basic fibroblast growth factor-dependent mechanism. J Biol Chem 1998, 273:32288-32296.

32. Fuentealba L, Carey DJ, Brandan E: Antisense inhibition of syndecan-3 expression during skeletal muscle differentiation accelerates myogenesis through a basic fibroblast growth factor-dependent mechanism. J Biol Chem 1999, 274:37876-37884.

33. Rapraeger AC, Krufka A, Olwin BB: Requirement of heparan sulfate for bFGF-mediated fibroblast growth and myoblast differentiation. Science 1991, 252:1705-1708.

34. van der Voort R, Taher TE, Wielenga VJ, Spaargaren M, Prevo R, Smit L, David G, Hartmann G, Gherardi E, Pals ST: Heparan sulfate-modified CD44 promotes hepatocyte growth factor/scatter factor-induced signal transduction through the receptor tyrosine kinase c-Met. J Biol Chem 1999, 274:6499-6506.

35. Brandan E, Carey DJ, Larraín J, Melo F, Campos A: Synthesis and processing of glypican during differentiation of skeletal muscle cells. Eur $J$ Cell Biol 1996, 71:170-176

36. Campos A, Núñez R, Koenig CS, Carey DJ, Brandan E: A lipid-anchored heparan sulfate proteoglycan is present in the surface of differentiated skeletal muscle cells: isolation and biochemical characterization. Eur J Biochem 1993, 216:587-595.

37. Larraín J, Alvarez J, Hassell JR, Brandan E: Expression of perlecan, a proteoglycan that binds myogenic inhibitory basic fibroblast growth factor, is down regulated during skeletal muscle differentiation. Exp Cell Res 1997, 234:405-412.

38. Gutiérrez J, Brandan E: A novel mechanism of sequestering fibroblast growth factor 2 by glypican in lipid rafts, allowing skeletal muscle differentiation. Mol Cell Biol 2010, 30:1634-1649.

39. Gutierrez J, Osses N, Brandan E: Changes in secreted and cell associated proteoglycan synthesis during conversion of myoblasts to osteoblasts in response to bone morphogenetic protein-2: role of decorin in cell response to BMP-2. J Cell Physiol 2006, 206:58-67.

40. Yaffe D, Saxel O: Serial passaging and differentiation of myogenic cells isolated from dystrophic mouse muscle. Nature 1977, 270:725-727.

41. Osses N, Gutierrez J, Lopez-Rovira T, Ventura F, Brandan E: Sulfation is required for bone morphogenetic protein 2-dependent Id1 induction. Biochem Biophys Res Commun 2006, 344:1207-1215.

42. Osses N, Brandan E: ECM is required for skeletal muscle differentiation independently of muscle regulatory factor expression. Am J Physiol Cell Physiol 2002, 282:C383-C394.

43. Droguett R, Cabello-Verrugio C, Riquelme C, Brandan E: Extracellular proteoglycans modify TGF- $\beta$ bio-availability attenuating its signaling during skeletal muscle differentiation. Matrix Biol 2006, 25:332-341. 
44. Lafreniere JF, Mills P, Bouchentouf M, Tremblay JP: Interleukin-4 improves the migration of human myogenic precursor cells in vitro and in vivo. Exp Cell Res 2006, 312:1127-1141.

45. Olguin HC, Santander C, Brandan E: Inhibition of myoblast migration via decorin expression is critical for normal skeletal muscle differentiation. Dev Biol 2003, 259:209-224.

46. Moscatelli D, Quarto N: Transformation of NIH 3T3 cells with basic fibroblast growth factor or the hst/K-fgf oncogene causes downregulation of the fibroblast growth factor receptor: reversal of morphological transformation and restoration of receptor number by suramin. J Cell Biol 1989, 109:2519-2527.

47. Rubin JS, Day RM, Breckenridge D, Atabey N, Taylor WG, Stahl SJ, Wingfield PT, Kaufman JD, Schwall R, Bottaro DP: Dissociation of heparan sulfate and receptor binding domains of hepatocyte growth factor reveals that heparan sulfate-c-met interaction facilitates signaling. J Biol Chem 2001, 276:32977-32983.

48. Roghani M, Moscatelli D: Basic fibroblast growth factor is internalized through both receptor-mediated and heparan sulfate-mediated mechanisms. J Biol Chem 1992, 267:22156-22162.

49. Zarnegar R, DeFrances MC, Oliver L, Michalopoulos G: Identification and partial characterization of receptor binding sites for HGF on rat hepatocytes. Biochem Biophys Res Commun 1990, 173:1179-1185.

50. Lin X, Perrimon N: Dally cooperates with Drosophila Frizzled 2 to transduce Wingless signalling. Nature 1999, 400:281-284.

51. Capurro MI, Xiang YY, Lobe C, Filmus J: Glypican-3 promotes the growth of hepatocellular carcinoma by stimulating canonical Wnt signaling. Cancer Res 2005, 65:6245-6254.

52. Yan D, Lin X: Drosophila glypican Dally-like acts in FGF-receiving cells to modulate FGF signaling during tracheal morphogenesis. Dev Biol 2007, 312:203-216.

53. Filmus J, Capurro M, Rast J: Glypicans. Genome Biol 2008, 9:224.

54. Deakin JA, Lyon M: Differential regulation of hepatocyte growth factor/ scatter factor by cell surface proteoglycans and free glycosaminoglycan chains. J Cell Sci 1999, 112:1999-2009.

55. Hartmann G, Prospero T, Brinkmann V, Ozcelik Ö, Winter G, Hepple J, Batley S, Bladt F, Sachs M, Birchmeier C, Birchmeier W, Gherardi E: Engineered mutants of HGF/SF with reduced binding to heparan sulphate proteoglycans, decreased clearance and enhanced activity in vivo. Curr Biol 1998, 8:125-134

56. Kemp LE, Mulloy B, Gherardi E: Signalling by HGF/SF and Met: the role of heparan sulphate co-receptors. Biochem Soc Trans 2006, 34:414-417.

57. Limpert AS, Karlo JC, Landreth GE: Nerve growth factor stimulates the concentration of TrkA within lipid rafts and extracellular signal-regulated kinase activation through c-Cbl-associated protein. Mol Cell Biol 2007, 27:5686-5698

58. Liu P, Ying Y, Ko YG, Anderson RG: Localization of platelet-derived growth factor-stimulated phosphorylation cascade to caveolae. J Biol Chem 1996, 271:10299-10303.

59. Gao X, Zhang J: Akt signaling dynamics in plasma membrane microdomains visualized by FRET-based reporters. Commun Integr Biol 2009, 2:32-34

60. Salani B, Briatore L, Contini P, Passalacqua M, Melloni E, Paggi A, Cordera R, Maggi D: IGF-I induced rapid recruitment of integrin $\beta_{1}$ to lipid rafts is caveolin-1 dependent. Biochem Biophys Res Commun 2009, 380:489-492.

61. Rybin VO, Xu X, Lisanti MP, Steinberg SF: Differential targeting of $\beta$ adrenergic receptor subtypes and adenylyl cyclase to cardiomyocyte caveolae: a mechanism to functionally regulate the CAMP signaling pathway. J Biol Chem 2000, 275:41447-41457.

62. Chun M, Liyanage UK, Lisanti MP, Lodish HF: Signal transduction of a G protein-coupled receptor in caveolae: colocalization of endothelin and its receptor with caveolin. Proc Natl Acad Sci U S A 1994, 91:11728-11732.

63. Monastyrskaya K, Hostettler A, Buergi S, Draeger A: The NK1 receptor localizes to the plasma membrane microdomains, and its activation is dependent on lipid raft integrity. J Biol Chem 2005, 280:7135-7146.

64. Dessy C, Kelly RA, Balligand $J L$, Feron O: Dynamin mediates caveolar sequestration of muscarinic cholinergic receptors and alteration in NO signaling. EMBO J 2000, 19:4272-4280.

65. Di Guglielmo GM, Le Roy C, Goodfellow AF, Wrana JL: Distinct endocytic pathways regulate TGF- $\beta$ receptor signalling and turnover. Nat Cell Biol 2003, 5:410-421. A published erratum appears in Nat Cell Biol 2003, 5:680.

66. Mineo C, Gill GN, Anderson RG: Regulated migration of epidermal growth factor receptor from caveolae. J Biol Chem 1999, 274:30636-30643.
67. Nakamura T, Sakai K, Matsumoto K: Hepatocyte growth factor twenty years on: much more than a growth factor. J Gastroenterol Hepatol 2011, 26(Suppl 1):188-202

68. Franz T, Kothary R, Surani MA, Halata Z, Grim M: The Splotch mutation interferes with muscle development in the limbs. Anat Embryol (Berl) 1993, 187:153-160.

69. Bober E, Brand-Saberi B, Ebensperger C, Wilting J, Balling R, Paterson BM, Arnold $\mathrm{HH}$, Christ $\mathrm{B}$ : Initial steps of myogenesis in somites are independent of influence from axial structures. Development 1994, 120:3073-3082.

70. Daston G, Lamar E, Olivier M, Goulding M: Pax-3 is necessary for migration but not differentiation of limb muscle precursors in the mouse. Development 1996, 122:1017-1027.

71. Huard J, Bouchard JP, Roy R, Malouin F, Dansereau G, Labrecque C, Albert N, Richards CL, Lemieux B, Tremblay JP: Human myoblast transplantation: preliminary results of 4 cases. Muscle Nerve 1992, 15:550-560.

72. Tremblay JP, Malouin F, Roy R, Huard J, Bouchard JP, Satoh A, Richards CL: Results of a triple blind clinical study of myoblast transplantations without immunosuppressive treatment in young boys with Duchenne muscular dystrophy. Cell Transplant 1993, 2:99-112.

73. Miller RG, Sharma KR, Pavlath GK, Gussoni E, Mynhier M, Lanctot AM, Greco CM, Steinman L, Blau HM: Myoblast implantation in Duchenne muscular dystrophy: the San Francisco study. Muscle Nerve 1997, 20:469-478.

74. Cornelison DD, Filla MS, Stanley HM, Rapraeger AC, Olwin BB: Syndecan-3 and syndecan- 4 specifically mark skeletal muscle satellite cells and are implicated in satellite cell maintenance and muscle regeneration. Dev Biol 2001, 239:79-94.

75. Galbiati F, Volonte D, Engelman JA, Scherer PE, Lisanti MP: Targeted downregulation of caveolin-3 is sufficient to inhibit myotube formation in differentiating $\mathrm{C} 2 \mathrm{C} 12$ myoblasts: transient activation of p38 mitogenactivated protein kinase is required for induction of caveolin-3 expression and subsequent myotube formation. J Biol Chem 1999, 274:30315-30321.

76. Ornitz DM, Xu J, Colvin JS, McEwen DG, MacArthur CA, Coulier F, Gao G, Goldfarb M: Receptor specificity of the fibroblast growth factor family. J Biol Chem 1996, 271:15292-15297.

77. Yamada M, Tatsumi R, Yamanouchi K, Hosoyama T, Shiratsuchi S, Sato A, Mizunoya W, Ikeuchi Y, Furuse M, Allen RE: High concentrations of HGF inhibit skeletal muscle satellite cell proliferation in vitro by inducing expression of myostatin: a possible mechanism for reestablishing satellite cell quiescence in vivo. Am J Physiol Cell Physiol 2010, 298:C465-C476.

78. Gill R, Hitchins L, Fletcher F, Dhoot GK: Sulf1A and HGF regulate satellitecell growth. J Cell Sci 2010, 123:1873-1883.

79. Larraín J, Cizmeci-Smith G, Troncoso V, Stahl RC, Carey DJ, Brandan E: Syndecan-1 expression is down-regulated during myoblast terminal differentiation: modulation by growth factors and retinoic acid. J Biol Chem 1997, 272:18418-18424.

80. Casar JC, Cabello-Verrugio C, Olguin H, Aldunate R, Inestrosa NC, Brandan E: Heparan sulfate proteoglycans are increased during skeletal muscle regeneration: requirement of syndecan-3 for successful fiber formation. J Cell Sci 2004, 117:73-84.

81. Jen $\mathrm{YH}$, Musacchio M, Lander AD: Glypican-1 controls brain size through regulation of fibroblast growth factor signaling in early neurogenesis. Neural Dev 2009, 4:33.

82. Anastasi S, Giordano S, Sthandier O, Gambarotta G, Maione R, Comoglio P, Amati P: A natural hepatocyte growth factor/scatter factor autocrine loop in myoblast cells and the effect of the constitutive Met kinase activation on myogenic differentiation. J Cell Biol 1997, 137:1057-1068.

83. Allen RE, Sheehan SM, Taylor RG, Kendall TL, Rice GM: Hepatocyte growth factor activates quiescent skeletal muscle satellite cells in vitro. J Cell Physiol 1995, 165:307-312.

84. Tatsumi R, Anderson JE, Nevoret CJ, Halevy O, Allen RE: HGF/SF is present in normal adult skeletal muscle and is capable of activating satellite cells. Dev Biol 1998, 194:114-128.

85. Tatsumi R, Hattori A, Ikeuchi Y, Anderson JE, Allen RE: Release of hepatocyte growth factor from mechanically stretched skeletal muscle satellite cells and role of pH and nitric oxide. Mol Biol Cell 2002, 13:2909-2918.

86. Wozniak AC, Pilipowicz O, Yablonka-Reuveni Z, Greenway S, Craven S, Scott E, Anderson JE: C-Met expression and mechanical activation of satellite cells on cultured muscle fibers. J Histochem Cytochem 2003, 51:1437-1445.

87. Zammit PS, Golding JP, Nagata Y, Hudon V, Partridge TA, Beauchamp JR: Muscle satellite cells adopt divergent fates: a mechanism for self-renewal? J Cell Biol 2004, 166:347-357. 
88. Zammit PS: All muscle satellite cells are equal, but are some more equal than others? J Cell Sci 2008, 121:2975-2982.

89. Pallafacchina G, Francois S, Regnault B, Czarny B, Dive V, Cumano A, Montarras D, Buckingham M: An adult tissue-specific stem cell in its niche: a gene profiling analysis of in vivo quiescent and activated muscle satellite cells. Stem Cell Res 2010, 4:77-91.

90. Kuang S, Gillespie MA, Rudnicki MA: Niche regulation of muscle satellite cell self-renewal and differentiation. Cell Stem Cell 2008, 2:22-31.

91. Cossu G, Tajbakhsh S: Oriented cell divisions and muscle satellite cell heterogeneity. Cell 2007, 129:859-861.

doi:10.1186/2044-5040-4-5

Cite this article as: Gutiérrez et al:: Glypican-1 regulates myoblast response to HGF via Met in a lipid raft-dependent mechanism: effect on migration of skeletal muscle precursor cells. Skeletal Muscle 2014 4:5.

\section{Submit your next manuscript to BioMed Central and take full advantage of:}

- Convenient online submission

- Thorough peer review

- No space constraints or color figure charges

- Immediate publication on acceptance

- Inclusion in PubMed, CAS, Scopus and Google Scholar

- Research which is freely available for redistribution 